\title{
CHARACTERISATION OF PELLETS MADE FROM OIL PALM RESIDUES IN COSTA RICA
}

\author{
CAROLINA TENORIO*; RÓGER MOYA* and JORRE VALAERT**
}

\begin{abstract}
Presently, there are around 67000 ha of oil palm (Elaeis guineensis) in Costa Rica. The resulting post-harvest residues are not being used currently. These residues can be employed for generation of heat by means of pelletisation. This study evaluates pellets fabricated with empty fruit bunches (EFB) and oil palm fruit mesocarp (OPFM), considering the physical (length, diameter, apparent density and moisture absorption), chemical ( $C$ and $N$ content, $C / N$ ratio, cellulose, lignin and extractives), energy (calorific value, ash, volatile and moisture content) and mechanical properties (mechanical durability and force at break) of the pellets, as well as the quality evaluation by means of X-ray densitometry and their efficiency in real conditions of use. Results obtained show few energy, physical and mechanical differences between both types of pellets. The greater differences appear at the chemical level where, in the case of OPFM, high oil or resin contents may be the cause. Both pellets showed density levels within the international ranges, although with internal variations, especially in OPFM. For both types of pellet, it is necessary to improve the combustion process in order to achieve better efficiency, especially with respect to residual mass and $\mathrm{O}_{2}$ emissions.
\end{abstract}

Keywords: biomass, fuel, pellet properties, domestic stove.

Date received: 27 October 2015; Sent for revision: 8 December 2015; Received in final form: 21 April 2016 ; Accepted: 22 April 2016.

\section{INTRODUCTION}

Oil palm (Elaeis guineensis) is one of the most economically important crops worldwide (Shuit et al., 2009; Lai et al., 2013). Processing of this crop generates approximately 100 million tonnes of residues annually, of which $54 \%$ correspond to empty fruit bunches (EFB), 30\% to palm kernel shells and 18\% to fibres (Chiew and Shimada, 2013). For processing plants, disposal of these scarcely exploited residues is an urgent and critical issue

\footnotetext{
Escuela de Ingeniería Forestal,

Instituto Tecnológico de Costa Rica

CIIBI, Apartado 159-7050,

Cartago, Costa Rica.

E-mail: rmoya@itcr.ac.cr

** Agrep Forestal S A, San Carlos, Alajuela, Costa Rica.
}

due to the increase in production costs involved in their management (Shuit et al., 2009). Currently, these residues decompose in open fields when incineration is not a viable alternative, which results in a significant loss of energy (Lam et al., 2015) and an increase in greenhouse effect gases as a result of the decomposition of biomass (Herrero et al., 2013).

Residues generated from the processing of the oil palm fruit can be used as biomass, specifically for generation of heat (Shuit et al., 2009) and electricity (Chiew and Shimada, 2013). However, some residues like the EFB are not commonly used as fuel due to their high moisture content and volume, which makes handling and transport difficult, making it necessary to search for alternatives to increase the energy concentration and thus, enhance the quality of these residues as energy sources (Nasrin et al., 2008). 
Pelletisation is an option broadly used to increase the energy concentration of biomass by eliminating its heterogeneity (Stelte et al., 2011). Pellets are employed in energy applications because they possess better physical and combustion characteristics and are easy to handle, store and transport (Razuan et al., 2011). According to Kerdsuwan and Laohalidanond (2011), the greater bulk density, lower moisture content and reduced particle sizes of pellets compared to non-transformed biomass makes them a preferable option for heat and energy production.

Much research has been carried out about the fabrication, processing conditions and characterisation of pellets made of residues from the processing of the oil palm. For example, Nasrin et al. (2008) found that the mixture of residues such as EFB and palm kernel shells for pellet manufacture can improve the properties of these materials, as their energy content increases up to a 5\% through the reduction of their moisture content. Razuan et al. (2011) studied the characteristics of the pelletisation process and determined the physical properties of pellets made from palm kernel shells and found good results regarding their properties. Lam et al. (2015) studied the effect of a steam treatment prior to pelletisation on the physical and mechanical properties of pellets made from EFB and palm kernel shells. However, despite many studies, most of these have focused on the use of residues such as empty fruit bunches and palm kernel shells, therefore information is limited concerning other types of residues, like the oil palm fruit mesocarp (OPFM).

Costa Rica is a small Central American country with a tropical climate that favours the establishment of oil palm plantations. Around 67000 ha of oil palm (INEC, 2015) are planted and the post-harvest residues of these plantations are not being used currently, with the resulting generation of problems, particularly as regards to the environment (Torres et al., 2004).

On the other hand, pellets have gained popularity in Costa Rica since some industries seek to convert from fossil-fuelled heat production to one from renewable sources, aiming at carbon neutrality. The rise in pellet production at national scale has led to the characterisation of pellets made from diverse agricultural and forestry crops (Tenorio et al., 2015a, b). In addition, because of the high availability of residues from the oil extraction process of the oil palm, the energy potential from these sources is not to be disregarded, hence, the need to characterise these materials as fuels, specifically residues EFB and OPFM, of which little information is available globally.

The following study has therefore the objective of evaluating the performance of pellets made from EFB and OPFM, considering the physical (length, diameter, apparent density and moisture absorption), chemical ( $\mathrm{C}$ and $\mathrm{N}$ content, $\mathrm{C} / \mathrm{N}$ ratio, cellulose, lignin and extractives), energy (calorific value, ash, volatile and moisture content) and mechanical properties (mechanical durability and force at break) of the pellets, as well as the quality evaluation by means of X-ray densitometry and efficiency under actual conditions of use.

\section{MATERIALS AND METHODS}

\section{Pellet Manufacturing Process}

EFB and OPFM were collected in two different production sites in Costa Rica: one plantation in the South Pacific Coast and the other in the Central Pacific Coast of Costa Rica. After extraction of the oil, EFB and OPFM were obtained separately during the production process. The fibre dimensions and chemical compositions of EFB and OPFM are shown in the Table 1 (Moya et al., 2013; 2015b). The collected material was then dried to a $10 \%$ moisture content following the method proposed by Tenorio and Moya (2012).

The pellet manufacturing process was carried out in Pelletics S A, located in San Carlos in the province of Alajuela (Costa Rica). The pelletisation process is detailed widely in Aragón-Garita et al. (2016).

\section{Properties of the Pellets}

The pellets' energy properties determined were: net calorific value, in accordance with the ASTM D5865 Standard (ASTM, 2004); ash content following the ASTM D1102 Standard (ASTM, 2013a); moisture content and percent volatile according to the ASTM D1762 Standard (ASTM, 2013b). The percentage of carbon (C), nitrogen $(\mathrm{N})$ and the $\mathrm{C} / \mathrm{N}$ ratio were determined with the Elementar Analysensysteme, model Vario Macro Cube. In the lignin quantification, the TAPPI T222 om-02 (TAPPI, 2002) method was used and for determination of cellulose the procedure used was the one followed by Seifert (1960). For $\mathrm{pH}$ determination, the methodology used was the one proposed by Moore and Johnson (1967). Little amounts of EFB and OPMF were sieved through $0.25 \mathrm{~mm}$ and $0.42 \mathrm{~mm}$ meshes (40 and 60 meshes, respectively).

Extractives content was determined in water (under hot and cool conditions) according to the ASTMD1110-84(ASTM, 2013c); in sodium hydroxide $(\mathrm{NaOH})$ (ASTM, 2013d); in an ethanol-toluene solution (ASTM, 2013e) and in dichloromethane (CH2-Cl2) (ASTM, 2013f).

For the physical properties, a representative random samples of 30 pellets were used for EFB and OPFM. To determine moisture absorption, 
pellets were placed in a desiccator containing a saturated solution of potassium nitrate at $22^{\circ} \mathrm{C}$ ( $21 \%$ equilibrium moisture content); pellets were weighed on a weekly basis until they reached a constant weight. Samples were weighed before and after this period. The absorption percentage was calculated with Equation (1). To determine the apparent density, a beaker at $500 \mathrm{ml}$ was used, and was determined by the ratio between the weight and the volume occupied by the pellets. The pellets' bulk density can be obtained by means of Equation (2). Ten pellets were randomly selected from the EFB and OPMF sets.

$$
\begin{aligned}
& \begin{array}{l}
\text { Humidity } \\
\text { absorption }(\%)
\end{array}=\frac{\text { Weight at } 21 \%(\mathrm{~g}) \text {-initial weight }(\mathrm{g})}{\text { Initial weight }(\mathrm{g})} \times 100 \\
& \text { Pellet bulk density }\left(\frac{\mathrm{g}}{\mathrm{cm}^{3}}\right)=\frac{\text { Pellet mass }(\mathrm{g})}{\text { Pellet volume }\left(\mathrm{cm}^{3}\right)}
\end{aligned}
$$

Pellet mechanical durability was determined by means of the DD Cent/TS 15210-1:2005 Standard (BSI, 2005). Ten representative pellet samples of $500 \mathrm{~g}$ were used. Durability was calculated using Equation (3). The other mechanical test determined was compression resistance. Ten pellets with an approximate length of $13 \mathrm{~mm}$ were randomly selected. The test was performed longitudinally on the pellet, according to the methodology proposed by Aarseth and Prestlokken (2003), using a 1 t Tinius Olsen universal test machine model H10KT.

$\begin{aligned} & \text { Mechanical } \\ & \text { durability }(\%)\end{aligned}=\frac{(\text { Weight pellets before the test }(\mathrm{g})}{(\text { Weight pellets after the test }(\mathrm{g})} \times 100$

\section{Pellet Density Measured by X-ray Densitometry}

The X-ray densitometry density measurement was performed in longitudinal and transversal directions on 10 randomly selected pellets fabricated with EFB and OPFM. For the densitometry measurement in longitudinal and transversal direction, the pellets were placed directly in the X-ray equipment's bracket. For densitometry in transversal direction, pellets samples of $1.8 \mathrm{~mm}$ thick were used. The exposure of the samples in longitudinal and transversal directions was performed using an X-ray scanner (Quintek Measurement Systems Inc., QTRS-01X model). Tenorio et al. (2015a) detail widely the X-ray densitometry measuring with this equipment.

Density profile provided by the X-scanner was used to determine the average pellet density. The density values calculated with the X-ray equipment were corrected with the correction factor. Once the correction factor was established, it was applied to each densitometry value evaluation. The correction was applied to the pellets' values of longitudinal and transversal directions, according to Tenorio et al. (2015a). Walker and Dobb (1988) proposed a methodology that calculates the density variation in wood by using the X-ray densitometry readings, which was used to calculate the coefficient of variation. The coefficient of variation was determined for variation in transversal direction and for variation in longitudinal direction.

\section{Combustion Evaluation of Pellets}

To evaluate the combustion of pellets, the stove employed was a Bmax Technology brand, model B-Half. A refractory brick kiln with $74 \mathrm{~cm}$ of width, $73 \mathrm{~cm}$ of depth and $30 \mathrm{~cm}$ of height was built. The recipient with the pellets was placed on a weighing scale with the purpose of establishing the pellet

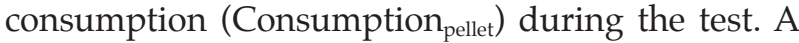
recipient was placed inside the kiln for collecting residual mass (ash, slag and unburned material) during the test. A temperature probe was placed at the flame outlet of the stove and another temperature probe was placed at $30 \mathrm{~cm}$ from the beginning of the flue, the former named as flame outlet temperature and the latter flue gas temperature. Additionally, the sensors to measure combustion gas were placed at this point. The information about this combustion test is detailed in Moya et al. (2015a).

Three combustion tests, lasting $1 \mathrm{hr}$ each, were performed. To determine the Consumption pelle by the stove during the test, the pellet mass was weighed before and after the hour of stove operation. During the hour of the test, the flame outlet temperature and the flue gas temperature were monitored by employing TESTO measurer (model 177-T4). For the determination of the residual mass (ash content, slag and unburned material), the recipient for its collection was placed from the beginning of the combustion test and retrieved at the end. Then, the residual mass was weighed and three samples were taken to determine the moisture content in it, in accordance with the ASTM D-5865 Standard (ASTM, 2004). Three samples were also taken to determine the real ash percentage contained in the residual mass, according to the ASTM 110284 standard (ASTM, 2013a). These parameters were named, respectively, 'moisture content of residual mass' and 'residual mass'.

Emissions were determined by employing a TESTO brand gas analyser model 350. Emissions determined were oxygen $\left(\mathrm{O}_{2}\right)$, carbon dioxide $\left(\mathrm{CO}_{2}\right)$, carbon monoxide $(\mathrm{CO})$, nitrous oxides $\left(\mathrm{NO}, \mathrm{NO}_{2}\right.$ and NOX) and sulphur dioxide $\left(\mathrm{SO}_{2}\right)$.

The data analysis of the combustion was performed from two aspects. The first aspect, relating to the general characteristics of the biomass combustion and the following parameters were determined: pellet mass flow or pellet mass consumed in time (Kg-pellet mass/hours), residual mass and ash content after pellet combustion, ash 
moisture content, flame outlet temperature and flue gas temperature. The second aspect of the combustion evaluated was the thermal analysis, in which heat loss due to dry flue gas and wet flue gas is evaluated, as well as the total heat loss, in order to finally establish the efficiency in combustion of the pellets. Concerning heat loss, the ASME PTC4 (2011) method was used, which is catalogued as indirect and calculates loss as follows and widely detailed in Moya et al. (2015a).

\section{Statistical Analysis}

A descriptive analysis was performed (median, standard deviation, maximum and minimum values) for the following variables: pellet length and diameter, calorific value, ash content, percent volatile, moisture content, apparent density, bulk density, absorption percentage, durability and force at break, $\mathrm{C}$ and $\mathrm{N}$ content, transversal and longitudinal density, consumption ${ }_{\text {pellet }}$ residual mass, flame temperature, flue gas temperature, parameter of emissions $\left(\mathrm{O}_{2}, \mathrm{CO}_{2}, \mathrm{CO}, \mathrm{NO}, \mathrm{NO}_{2}\right.$, $\mathrm{NOx}$ and $\mathrm{SO}_{2}$ ), heat loss (dry and wet) and efficiency of pellet combustion. In addition, it was determined whether variables complied with the premises of normal distribution, homogeneity of variances, as well as the presence of extreme values. A variance analysis was applied to verify the existence of significant differences among the averages of the variables $(\mathrm{P}<0.05)$. Tukey's test was carried out to determine the statistical differences between EFB and OPMF, for the mean value of each of the abovementioned values.

\section{RESULTS}

\section{Properties of the Pellets}

Table 1 shows results obtained for the energy, physical and mechanical properties evaluated. In Table 1, few differences can be observed between pellets from EFB and OPFM. Among energy properties, it can be seen that differences only appeared in the calorific value, where OPFM pellets showed a greater value $\left(15830.30 \mathrm{~kJ} \mathrm{~kg}^{-1}\right)$ in relation to those from EFB (14 $181.80 \mathrm{~kJ} \mathrm{~kg}^{-1}$ ) (Table 1). As for physical properties, differences are seen only in the length and moisture absorption of the pellets, where EFB pellets show greater length $(22.94 \mathrm{~mm})$, while OPFM pellets show greater moisture absorption percentage $(5.66 \%)$. Regarding the mechanical properties, no differences were observed in the mechanical durability, whereas EFB pellets showed higher values of force at break (Table 1).

Among the chemical properties, EFB pellets showed higher values for cellulose (Table 2) and $\mathrm{C}, \mathrm{C} / \mathrm{N}$ ratio (Table 3) and, while OPFM pellets showed higher $\mathrm{N}$ percentage (Table 2). Regarding $\mathrm{pH}$, ash content and lignin, no differences were observed between both types of pellets (Table 2 ). In the evaluation of extractives, it was found that, in general, EFB pellets show a statistically lower amount of extractives than that present in OPFM pellets, with the exception of extractives in dichloromethane, which do not show differences in their amounts between these two parts of the oil palm (Table 2).

\section{Pellet Density Measured by X-ray Densitometry}

In the evaluation of density by X-ray densitometry, it can be observed that no differences appear between the density of pellets from EFB and OPFM, not longitudinally nor transversally (Table 4). However, differences do appear in the variation of this density, measured by the coefficient of variation in both longitudinal and transversal directions. Coefficient of variation of the density in the longitudinal direction in OPFM pellets shows a higher value $(6.45 \%)$ than in EFB pellets. Another important result to observe is that coefficients of variation in the transversal direction are higher than those obtained in the longitudinal direction.

TABLE 1. ENERGY, PHYSICAL AND MECHANICAL PROPERTIES OF THE TWO TYPES OF PELLETS EVALUATED

\begin{tabular}{llcc}
\hline Pellet properties & \multicolumn{1}{c}{ Parameter } & Empty fruit bunches & Oil palm fruit mesocarp \\
\hline \multirow{2}{*}{ Energy } & Calorific value $\left(\mathrm{kJ} \mathrm{kg}^{-1}\right)$ & $14181.80^{\mathrm{B}}(9.74)$ & $15830.80^{\mathrm{A}}(5.69)$ \\
& Ash content $(\%)$ & $5.75^{\mathrm{A}}(12.69)$ & $6.24^{\mathrm{A}}(20.88)$ \\
& Volatile content $(\%)$ & $71.70^{\mathrm{A}}(0.13)$ & $72.41^{\mathrm{A}}(0.78)$ \\
& Moisture content $(\%)$ & $9.05^{\mathrm{A}}(6.87)$ & $9.20^{\mathrm{A}}(5.06)$ \\
\multirow{2}{*}{ Physical } & Length (mm) & $22.94^{\mathrm{A}}(9.59)$ & $17.34^{\mathrm{B}}(26.68)$ \\
& Diameter (mm) & $6.09^{\mathrm{A}}(2.01)$ & $6.12^{\mathrm{A}}(4.08)$ \\
& Moisture absorption $(\%)$ & $5.06^{\mathrm{B}}(24.87)$ & $5.66^{\mathrm{A}}(14.72)$ \\
& Apparent density $\left(\mathrm{kg} \mathrm{m}^{-3}\right)$ & $575.00^{\mathrm{A}}(1.53)$ & $595.80^{\mathrm{A}}(1.62)$ \\
Mechanical & Mechanical durability $(\%)$ & $92.76^{\mathrm{A}}(0.72)$ & $92.82^{\mathrm{A}}(1.38)$ \\
& Force of break (N) & $563.20^{\mathrm{A}}(28.37)$ & $520.06^{\mathrm{B}}(34.33)$ \\
\hline
\end{tabular}

Note: Values between parentheses indicate the variation coefficient; different characters for each parameter indicate statistical significances at $95 \%$. 
TABLE 2. FIBRE DIMENSION AND CHEMICAL COMPOSITION OF OIL PALM FRUIT

\begin{tabular}{lll}
\hline Fibre parameters & \multicolumn{2}{c}{ Part of oil palm } \\
\cline { 2 - 3 } & \multicolumn{1}{c}{ Fruit } & \multicolumn{1}{c}{ Bunch } \\
\hline Length $(\mathrm{mm})$ & $0.86^{\mathrm{A}}(0.21)$ & $0.67^{\mathrm{B}}(0.20)$ \\
Diameter $(\mu \mathrm{m})$ & $23.88^{\mathrm{A}}(5.22)$ & $16.91^{\mathrm{B}}(3.04)$ \\
Lumen $(\mu \mathrm{m})$ & $16.11^{\mathrm{A}}(4.94)$ & $9.83^{\mathrm{B}}(2.37)$ \\
Cell wall $(\mu \mathrm{m})$ & $3.89^{\mathrm{A}}(0.66)$ & $3.54^{\mathrm{B}}(0.71)$ \\
pH & $5.72^{\mathrm{A}}(0.12)$ & $6.03^{\mathrm{A}}(1.17)$ \\
Cellulose $(\%)$ & $39.19^{\mathrm{A}}(1.58)$ & $36.38^{\mathrm{B}}(1.03)$ \\
Lignin $(\%)$ & $31.78^{\mathrm{A}}(8.36)$ & $30.99^{\mathrm{A}}(15.87)$ \\
Cool water & $12.58^{\mathrm{B}}(8.09)$ & $14.29^{\mathrm{A}}(4.72)$ \\
Hot water & $15.02^{\mathrm{B}}(5.25)$ & $17.72^{\mathrm{A}}(8.52)$ \\
NaOH at $1 \%$ & $42.73^{\mathrm{B}}(8.33)$ & $65.98^{\mathrm{A}}(2.62)$ \\
Ethanol toluene & $10.48^{\mathrm{B}}(2.61)$ & $12.44^{\mathrm{A}}(2.60)$ \\
Dichloromethane & $8.36^{\mathrm{A}}(13.35)$ & $8.50^{\mathrm{A}}(3.16)$ \\
\hline
\end{tabular}

Note: The lower case letters next to this value indicates that the values are statistically different at a confidence level of $95 \%$. Source: Moya et al. (2013; 2015b).

Longitudinal and transversal density profiles confirm the differences in the variation of the density in both longitudinal and transversal directions (Figure 1). In the longitudinal direction, it can be observed that EFB pellets possess a uniform pattern of density variation (Figure 1a), whereas OPFM pellets possess an irregular pattern (Figure $1 b$ ). Regarding the transversal direction, it is seen that both pellet types possess an irregular variation pattern (Figures $1 c$ and 1d).

\section{Characterisation of the Combustion Process of the Pellets}

In the evaluation of the pellet mass consumption in the domestic stove, no differences were found between the two pellet types regarding ash content of the residual mass and flame outlet temperature (Table 5). Meanwhile, moisture content of the residual mass and flue gas temperature values were higher in EFB pellets $\left(3.62 \%\right.$ and $28.50^{\circ} \mathrm{C}$ respectively). Figure $2 b$ presents the behaviour of the flame outlet temperature of the stove's flame and the flue gas temperature for both types of pellet. Greater irregularity can be observed in the flame outlet temperature of EFB pellets. Variation of the temperature, measured by its coefficient of variation at the two points of measurement - at the outlet of the flame and the flue - was higher at the flame outlet in comparison to flue gas temperature for both types of pellet; EFB pellets showed the highest values for both temperatures (Figure 2c).

Regarding gas emissions (Table 6), again it was found that there is little variation between the two pellet types, differences appearing only in the $\mathrm{CO}_{2}$ levels. OPFM pellets showed the higher values $(5.15 \%)$. Additionally, no presence of $\mathrm{SO}_{2}$ was detected in the evaluation of emissions.

In the evaluation of the remaining parameters of the combustion test, it was observed that heat loss is greater in EFB pellets $(66.78 \%$ ) than in OPFM pellets $(60.54 \%)$. Meanwhile, dry flue loss levels were lower than those of wet flue loss for both types of pellet (Figure $2 b$ ). Consequently, efficiency was greater in OPFM pellets $(39.46 \%)$ when compared to EFB pellets $(33.22 \%)$.

TABLE 3. CARBON PROPERTIES OF THE TWO TYPES OF PELLETS EVALUATED

\begin{tabular}{clcc}
\hline Pellet properties & \multicolumn{1}{c}{ Parameters } & Empty fruit bunches & Oil palm fruit mesocarp \\
\hline Chemical & Carbon $(\% \mathrm{w} / \mathrm{w})$ & $44.49^{\mathrm{A}}(1.43)$ & $42.70^{\mathrm{B}}(0.62)$ \\
& Nitrogen content $(\% \mathrm{w} / \mathrm{w})$ & $0.68^{\mathrm{B}}(0.84)$ & $1.70^{\mathrm{A}}(1.89)$ \\
& $\mathrm{C} / \mathrm{N}$ ratio & $65.10^{\mathrm{A}}(2.10)$ & $25.20^{\mathrm{B}}(1.68)$ \\
\hline
\end{tabular}

Note: Values between parentheses indicate the variation coefficient; different characters for each parameter indicate statistical significances at $95 \%$.

TABLE 4. DENSITY AND ITS VARIATION OBTAINED BY X-RAY DENSITOMETRY IN TRANSVERSAL AND LONGITUDINAL DIRECTIONS FOR THE TWO TYPES OF PELLETS EVALUATED

\begin{tabular}{clll}
\hline \multicolumn{2}{c}{ Parameter } & Empty fruit bunches & Oil palm fruit mesocarp \\
\hline \multirow{2}{*}{ Longitudinal direction } & Average $\left(\mathrm{kg} \mathrm{m}^{-3}\right)$ & $1232.60^{\mathrm{A}}$ & $1192.25^{\mathrm{A}}$ \\
& Coefficient of variation $(\%)$ & $4.98^{\mathrm{B}}$ & $6.45^{\mathrm{A}}$ \\
\multirow{2}{*}{ Transversal direction } & Average $\left(\mathrm{kg} \mathrm{m}^{-3}\right)$ & $1232.60^{\mathrm{A}}$ & $1192.25^{\mathrm{A}}$ \\
& Coefficient of variation $(\%)$ & $11.00^{\mathrm{A}}$ & $12.70^{\mathrm{A}}$ \\
\hline
\end{tabular}

Note: Different characters for each parameter indicate statistical significances at 95\%. 

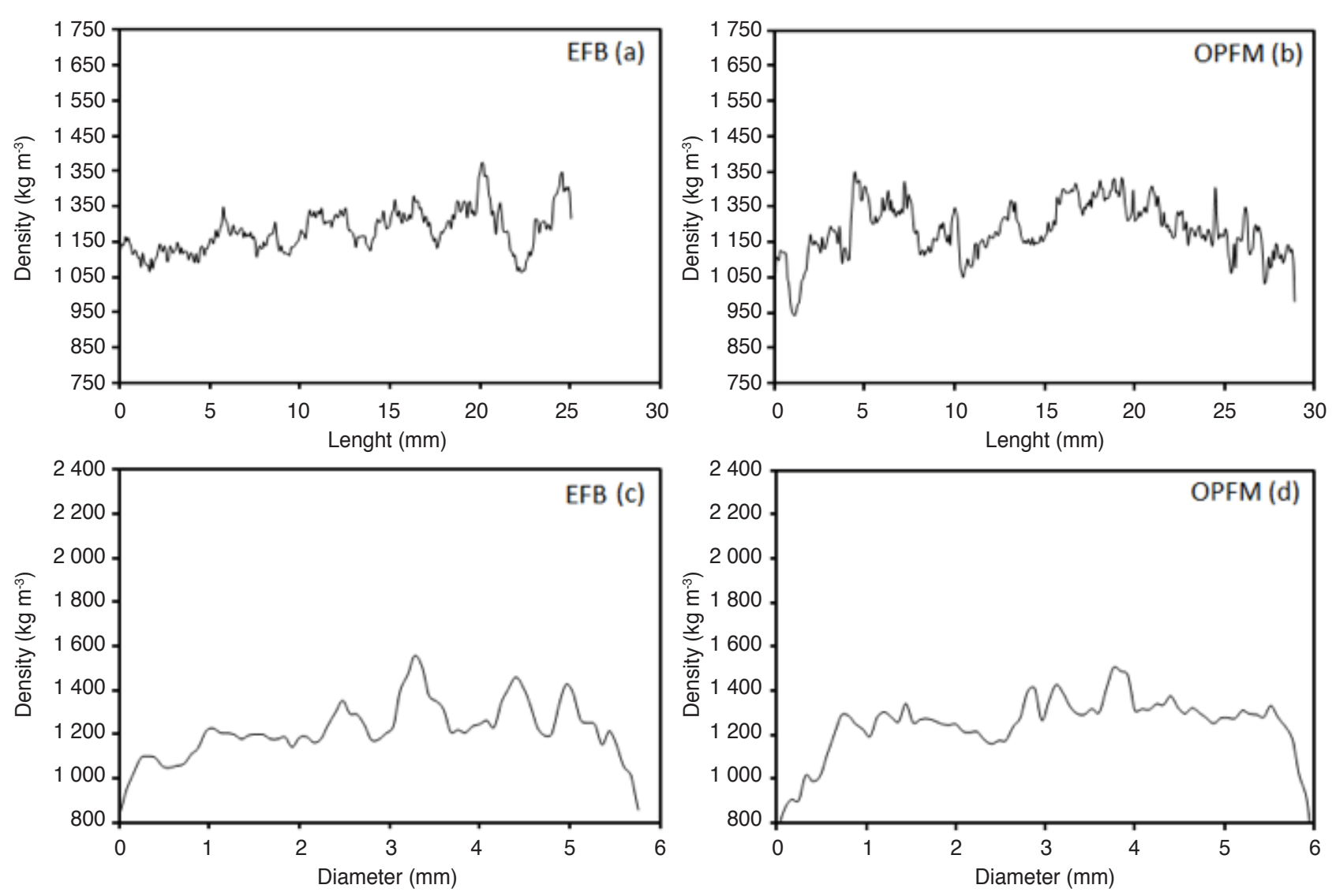

Figure 1. Density variation in pellet length in empty fruit bunches ( $E F B$ ) (a) and oil palm fruit mesocarp (UPFM) (b), and in pellet diameter in EFB (c) and OPFM $(d)$.

TABLE 5. PELLET CONSUMPTION RATES, CHARACTERISTICS OF THE ASHES AND TEMPERATURES FOUND IN THE COMBUSTION TESTS OF THE TWO TYPES OF PELLETS EVALUATED

\begin{tabular}{lcc}
\hline \multicolumn{1}{c}{ Parameter } & Empty fruit bunches & Oil palm fruit mesocarp \\
\hline Consumptionpellet at flue $\left(\mathrm{kg} \mathrm{hr}^{-1}\right)$ & $3.11^{\mathrm{A}}(7.80)$ & $3.36^{\mathrm{A}}(3.68)$ \\
Residual mass $(\%)$ & $4.06^{\mathrm{A}}(25.29)$ & $3.71^{\mathrm{A}}(34.86)$ \\
Ash content of residual mass $(\%)$ & $66.63^{\mathrm{A}}(15.65)$ & $68.36^{\mathrm{A}}(3.10)$ \\
Moisture content of residual mass $(\%)$ & $3.62^{\mathrm{A}}(0.00)$ & $3.33^{\mathrm{B}}(0.00)$ \\
Flame outlet temperature $\left({ }^{\circ} \mathrm{C}\right)$ & $543.87^{\mathrm{B}}(3.06)$ & $612.39^{\mathrm{A}}(0.00)$ \\
Flue gas temperature $\left({ }^{\circ} \mathrm{C}\right)$ & $284.37^{\mathrm{B}}(3.25)$ & $322.44^{\mathrm{A}}(0.00)$ \\
\hline
\end{tabular}

Note: Values between parentheses indicate the variation coefficient; different characters for each parameter indicate statistical significances at $95 \%$.

TABLE 6. EMISSIONS INSIDE THE STOVE OF THE TWO TYPES OF PELLETS EVALUATED

\begin{tabular}{lll}
\hline Parameter & $\begin{array}{c}\text { Empty fruit } \\
\text { bunches }\end{array}$ & $\begin{array}{c}\text { Oil palm fruit } \\
\text { mesocarp }\end{array}$ \\
\hline Oxygen $(\%)$ & $17.03^{\mathrm{A}}(2.06)$ & $18.20^{\mathrm{A}}(6.22)$ \\
$\mathrm{CO}_{2}(\%)$ & $3.97^{\mathrm{B}}(3.85)$ & $5.15^{\mathrm{A}}(6.87)$ \\
$\mathrm{CO}(\mathrm{ppm})$ & $622.00^{\mathrm{A}}(0.00)$ & $1441.50^{\mathrm{A}}(0.00)$ \\
$\mathrm{NO}(\mathrm{ppm})$ & $142.00^{\mathrm{A}}(10.93)$ & $175.50^{\mathrm{A}}(76.15)$ \\
$\mathrm{NO}_{2}(\mathrm{ppm})$ & $0.33^{\mathrm{A}}(173.21)$ & $1.50^{\mathrm{A}}(141.42)$ \\
$\mathrm{NO}_{x}(\mathrm{ppm})$ & $142.33^{\mathrm{A}}(10.55)$ & $175.50^{\mathrm{A}}(76.15)$ \\
$\mathrm{SO}_{2}(\mathrm{ppm})$ & - & - \\
\hline
\end{tabular}

Note: Different characters for each parameter indicate statistical significances at $95 \%$.

\section{DISCUSSION}

\section{Properties of the Pellets}

The values obtained for the calorific value (14 $181 \mathrm{~kJ} \mathrm{~kg}^{-1}$ for EFB and $15830 \mathrm{~kJ} \mathrm{~kg}^{-1}$ for OPFM) are lower than those reported by Munawar and Subiyanto (2014), which presented values within the range of 15500 to $17550 \mathrm{~kJ} \mathrm{~kg}^{-1}$ for EFB pellets and from 15950 to $19760 \mathrm{~kJ} \mathrm{~kg}^{-1}$ for OPFM pellets. With regard to the ash content, Lam et al. (2015) report ash contents of $5.47 \%$ for EFB pellets, which are slightly lower than those obtained in this work (5.75\% and 6.24\%). High ash contents (of over $4 \%$ ) can lead to corrosion of the stoves or kilns 

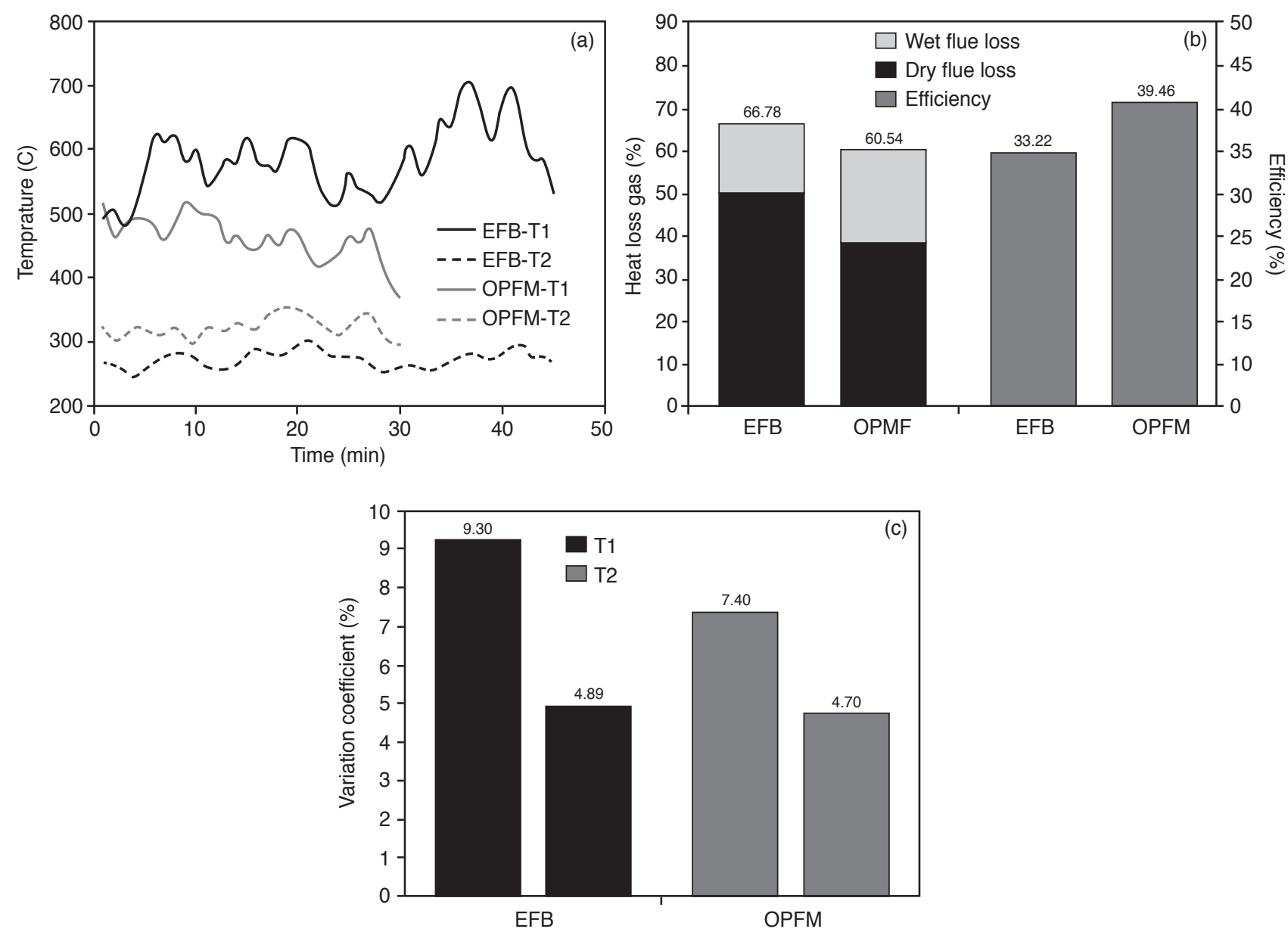

Figure 2. A segment of the process for empty fruit bunches (EFB) and oil palm fuit mesocarp (OPFM) (a), dry and wet flue heat losses and efficiency (b), and the variation coefficient of flame outlet and flue gas temperatures for the two types of pellets evaluated (c).

Note: T1: flame outlet temperature; T2: flue gas temperature.

and cause wear of the equipment due to abrasion (Mande, 2009). Manipulation of post-combustion of pellets manufactured from EFB and OPFM is more difficult, due to the high ash content produced. This difference can be attributed to the difference precedence of raw material.

The percent volatile of pellets obtained in this study (Table 2) is lower than that obtained by Sukiran et al. (2009) for EFB pellets, for which the reported value is $81.90 \%$. And this difference can be again attributed to different growing conditions of oil palm (Chiew and Shimada, 2013). High values (over $30 \%$ ) of volatiles produce more heat during the combustion process, which causes pellets to burn more quickly and thus be less convenient as fuels (Jain, 1994; Kataki and Konwer, 2002). With regard to $\mathrm{MC}$, Lam et al. (2015) reported $13.5 \%$ in EFB pellets, higher value than the one obtained in this study. It has been noted that MC of the pellets should range between $8 \%$ and $12 \%$ in order to achieve good performance in burners (Lehtikangas, 2001), which indicates that the moisture contents obtained are optimal.

Regarding evaluation of the physical properties, values of $5.06 \%$ in EFB and $5.66 \%$ in OPFM for moisture absorption are considered adequate, since values from $3 \%$ to $5 \%$ are pointed out as adequate for this type of product, as additional increase in the moisture absorbed could result in the decrease of quality and hardness of pellets (Fasina, 2008). The values obtained for bulk density (Table 4) are congruent with those found in pellets manufactured from corn, wheat and sorghum residues, where values ranged from $479 \mathrm{~kg} \mathrm{~m}^{-3}$ to $649 \mathrm{~kg} \mathrm{~m}^{-3}$ (Theererattananoona et al., 2011).

Evaluation of the mechanical properties is important as these define the capacity of pellets to resist destructive loads and forces during transport (Tabil and Sokhansanj, 1996). In this case, the values found for mechanical durability (Table 1) are considered acceptable, according to classification by Colley et al. (2006), who establish a durability of more than $80 \%$ within the 'acceptable' category. Values found for force at break (Table 1) are superior to those obtained by García-Maraver et al. (2010) for pellets fabricated with olive tree branches (209.18 $\mathrm{N})$. The pellet fabricated with oil palm residues has higher resistance than olive branches.

Regarding the chemical properties, the $\mathrm{C}$ values obtained are lower than those reported by 
Wahi et al. (2009), who report C values of $46.84 \%$ for raw material of EFB; the same authors report $\mathrm{N}$ percentages greater $(0.73 \%)$ than those obtained in this study for EFB pellets, although lower than those obtained here for OPFM (Table 3). Law et al. (2007) report a cellulose percentage of $62.9 \%$ for fibrous strands of EFB, which is higher than the value found for the pellets analysed in this study. The opposite occurs with the lignin percentage, for which the same authors report a value of $18.8 \%$, which is lower than the one obtained in this study (Table 2). Low values of carbon content and cellulose content do not favour the combustion process (Moya and Tenorio, 2013), which means this factor may have an influence on the low calorific value of the manufactured pellets. Again, the differences between ours results and other studies can be attributed to difference in chemical compositions (Chiew and Shimada, 2013).

When evaluating differences in the chemical, calorific and mechanical characteristics of the EFB and OPFM pellets, it was observed that there are few differences between them (Table 2). Regarding differences in the calorific value, these can be attributed to the high content of resins and extractives present in the OPFM pellets (Table 1). According to Demirbas (2009) and White (1987), elevated contents of extractives and resins such as wax, like the ones found in OPFM pellets (Table 1 ), tend to increase the calorific value of materials (Table 1).

Another difference found between EFB and OPFM pellets is their capacity for moisture absorption, which is also explained by the content of extractives in cold and hot water for OPFM. The high values for extractives in water for OPFM (Table 1) suggest that this material shows greater affinity to water, thus increasing its moisture absorption (Table 1).

Concerning the differences in the force at break (Table 1), Rhén et al. (2005) note that the compressive strength is directly influenced by the MC. However, in this case no differences are observed in the MC between both types of pellets (Table 1 ), indicating that other factors may be affecting the mechanical resistance. It is possible that EFB pellets, which present higher force at break, have types of resins or waxes that facilitate compaction of this material.

One important aspect to highlight is that the greatest amount of differences appeared in the chemical composition of both types of residues. Cellulose and lignin contents determine the properties of future products to be manufactured from materials presenting a high content of these polymers (John and Thomas, 2008). Particularly, in pellet fabrication chemical properties determine the calorific values (Moya and Tenorio, 2013). Additionally, biomass with high lignin content will produce high calorific values since lignin, due to its low oxidation levels, has a high heat content for combustion, while cellulose has a relatively low heat content due to its high oxidation levels (Kumar et al., 1992).

Extractives are non-structural or secondary components made of many lignocellulose materials, in which a great number and variety of components may be found (Tamaki and Mazza, 2010). Moreover, the percentages of extractives present in different lignocellulose residues have different effects depending on their prospective uses, and it is important to understand such effects (Trianoski et al., 2011). For example, Chen et al. (2007) and Thammasouk et al. (1997) affirm that water and ethanol extractives from different lignocellulose materials may be composed of non-structural sugars, organic acids, organic material, nitrogenous material, greases and other minor compounds. Those extractives, once dissolved in the aforementioned solvents, do not allow for part of the lignin to precipitate when using lignocellulose residues in ethanol production. In this study, it was observed

TABLE 7. COMPARISON FOR THE PROPERTIES OF THE TWO PELLETS EVALUATED WITH THE SS 187120 STANDARD FOR FUEL PELLETS

\begin{tabular}{|c|c|c|c|c|c|}
\hline Parameter & Group 1 & Group 2 & Group 3 & $\begin{array}{c}\text { Empty } \\
\text { fruit } \\
\text { bunches }\end{array}$ & $\begin{array}{l}\text { Oil palm } \\
\text { fruit } \\
\text { mesocarp }\end{array}$ \\
\hline $\begin{array}{l}\text { Diameter and } \\
\text { lengthin } \\
\text { producer's store }\end{array}$ & $\begin{array}{c}\text { To be stated } \\
\text { as max } 4 \\
\text { times } \varnothing\end{array}$ & $\begin{array}{c}\text { To be stated } \\
\text { as max } 5 \\
\text { times } \varnothing\end{array}$ & $\begin{array}{c}\text { To be stated } \\
\text { as max } 5 \\
\text { times } \varnothing\end{array}$ & 22.94 & 17.34 \\
\hline $\begin{array}{l}\text { Bulk density } \\
\left(\mathrm{kg} \mathrm{m}^{-3}\right)\end{array}$ & $\geq 600$ & $\geq 500$ & $\geq 500$ & 575 & 595.80 \\
\hline Ash content $(\%)$ & $\leq 0.7$ & $\leq 1.5$ & $\leq 1.5$ & 5.75 & 6.24 \\
\hline Calorific value $\left(\mathrm{MJ} \mathrm{kg}^{-1}\right)$ & $\geq 16.9$ & $\geq 16.9$ & $\geq 15.1$ & 14.18 & 15.83 \\
\hline Moisture content $(\%)$ & $\leq 10$ & $\leq 10$ & $\leq 10$ & 9.05 & 9.20 \\
\hline
\end{tabular}


that these extractives may have some effect on the quality of the pellet, especially on the properties related to moisture absorption, and may as well affect the calorific value of both types of pellet.

Table 7 shows the comparison of properties obtained in pellets fabricated with EFB and OPFM and different group provided by the Swedish Standard SS 187120 (SIS, 1998). It is observed that according to pellet length and MC of EFB and OPFM, they can be located in any of the three groups. While for bulk density only the EFB and OPFM is located in Groups 2 and 3. According to calorific values, EFB pellets is classified in any group, but OPFM pellet is located in Group 3. Finally, the high values of ash content for EFB or OPFM pellets allowed in SS Standard. According with above analysis, the pellets fabricated with EFB and OPFM can be used or sell as one or two Swedish Standard classifications.

\section{Pellet Density Measured by X-ray Densitometry}

Average densities observed for the pellets (1233 $\mathrm{kg} \mathrm{m}^{-3}$ in EFB and $1192 \mathrm{~kg} \mathrm{~m}^{-3}$ in OPFM) are within the range established by the German Standard DIN 51731, from $1000 \mathrm{~kg} \mathrm{~m}^{-3}$ to $1400 \mathrm{~kg} \mathrm{~m}^{-3}$ (Deutsches Institut fut Normung, 1996). When it is rationed these values with those obtained by Lam et al. (2015), it is observed that the values reported by Lam et al. (2015) $\left(1140 \mathrm{~kg} \mathrm{~m}^{-3}\right)$ in EFB pellets is greater than those obtained in our study.

Evaluation of density by X-ray densitometry showed that EFB pellets presented the most uniform density profiles in the longitudinal direction (coefficient of variation of $4.98 \%$ ) (Figure 1 ), whereas in the transversal direction both types of pellet showed irregular profiles (Figure 1). This variation of the density profiles of the pellets in the longitudinal and transversal directions (Table 4, Figure 1) is a consequence of the size of the particles conforming them, of the internal structure of their materials and of the temperature and pressure applied to them during the pelletisation process (Rhén et al., 2005). Concerning this, some studies suggest that the smaller the size of the particles or the size of the particles not uniform, the greater is the density of the pressing temperature and the applied pressure are the factors possibly affect the variation of density (Husain et al., 2002; Rhén et al., 2005; Gilbert et al., 2009; Lehtikangas, 2001; Larsson et al., 2008; Bergstrom et al., 2008; Serrano et al., 2011). Thus, variations in these factors are likely to cause variation in the density profile of the pellets evaluated.

\section{Characterisation of the Combustion Process of the Pellets}

In general, it was observed that the flow of mass of the pellet is, on average, $3.16 \mathrm{~kg} \mathrm{hr}^{-1}$ (Table
5). Variation of the pellet consumption was highly significant due to the $\mathrm{MC}_{\text {pellet }}$ and the $\mathrm{N}, \mathrm{NO}, \mathrm{NO}_{2^{\prime}}$ NOx content (Table 6), which goes in accordance with what was reported by Dai and Grace (2011) and Obernberger and Thek (2004). However, variation in the consumption is affected by other properties of the pellets, such as their energy, physical, mechanical and chemical characteristics (Tables 1 to 3). Carvalho et al. (2013) note that these properties of the pellets affect the feeding of pellets into the combustion system when a feeding screw is used, as is the case with the feeding system of the stove employed for this study.

Residual mass is composed of ash, slag and non-burnt material (Lindström et al., 2010). A high percentage of residual material produces problems in the feeding system of pellet burners, as it tends to accumulate at the exit (Öhman et al., 2004) and contributes to the increase in nitrate emissions (Carvalho et al., 2013). Results obtained for residual mass and the amount of ash present in it (Table 5) indicate that combustion ought to be improved in order to achieve $100 \%$ ash slag.

With regard to temperature, both at the flame outlet and in the flue, a difference is again observed between the two types of pellet (Table 4), the temperatures being higher in OPMF pellets. This has the advantage that the desired temperatures for a specific use would be reached within less time; this type of pellet additionally shows a more stable temperature than EFB pellets (Figures $2 a$ and $2 c$ ). The high temperatures reached in OPFM pellets can again be attributed to the different energy, physical, mechanical and chemical characteristics of the pellets (Tables 2 to 4), which have an influence on combustion processes (Moya et al., 2015a). The $\mathrm{CO}_{2}$ emissions are lower than $5.15 \%$, which represents an advantage in biomass; however, these emissions must be managed more carefully in order to further lower this value. Regarding $\mathrm{O}_{2}$ emissions, the average totalled $17 \%$ (Table 6), a value considered high as it should be of approximately 10\% (García-Maraver et al., 2010). This indicates that an adjustment of the manufacturing design is due in order to diminish $\mathrm{O}_{2}$ emissions.

Meanwhile, the data obtained from both types of pellets are highly variable for $\mathrm{CO}$ emissions (Table 6). Some authors (García-Maraver et al., 2010; Verma et al., 2012; Rabaçal et al., 2013) report values inferior to 2000 ppm in $17 \%$ of $\mathrm{O}_{2}$, far superior to those of the two types of pellet studied here, which thus remain within the normal range. For NO and NO the values found are also highly variable between the types, again being comparable to the studies performed by García-Maraver et al. (2010), Verma et al. (2012) and Rabaçal et al. (2013). Moreover, Limousy et al. (2013) catalogue emission values inferior to $100 \mathrm{ppm}$ as low, therefore EFB and OPMF pellets are catalogued as slightly high in the emissions of this type of gas. The 
high $\mathrm{NO}$ and $\mathrm{NO}_{\mathrm{x}}$ emissions are due to the nitrogen content of the biomass (Limousy et al., 2013).

Dry heat loss, as expected, is higher than wet heat loss (Figure 2b), as the pellets manufactured show low moisture levels $(10 \%-12 \%)$. This behaviour is consistent with results reported by Roy et al. (2011). However, a difference between the total heat loss of this study and that reported by Roy et al. (2011) is that loss in the present study was higher. While here the loss varied from $40 \%$ to $50 \%$ (Figure $4 b$ ), Roy et al. (2011) report $37 \%$ for wood pellets. The high differences in dry heat loss are attributed to the fact that, during combustion tests, hot air was not used in any type of work, thus flowing up the flue and rendering few differences between the two points of measurement that serve as reference for calculation of dry heat loss [Equation (10)].

Differences in dry heat loss and wet heat loss at the flue are attributed to the combustion process itself and to the properties of the pellets. In the case of dry air, variations were due to $\mathrm{O}_{2}$ and $\mathrm{CO}_{2}$ emissions during combustion (a factor related to the combustion process) and to the $\mathrm{MC}$ and calorific value of the pellet (factors related to pellet properties) (Moya et al., 2015a). For example, a low $\mathrm{O}_{2}$ content indicates that the combustion process is being performed adequately (Abuelnuor et al., 2014) and thus, an increase in efficiency takes place.

\section{CONCLUSION}

The results of the present study confirmed that pellet fabricated with EFB and OPFM are a promising feedstock for biomass production with adequate energy properties and could play an important role as a bioenergy and environmental benefits.

Pellets manufactured from EFB and OPFM show slightly low calorific values $\left(15830 \mathrm{~kJ} \mathrm{~kg}^{-1}\right.$ and $14181 \mathrm{~kJ} \mathrm{~kg}^{-1}$ ) compared to other types of biomass, probably due to the high ash contents and percent volatiles, which have a negative influence on the combustion potential. However, both types of pellets present adequate physical and mechanical properties that ensure their quality and hardness.

Pellets from EFB and OPFM showed differences in the calorific value, moisture absorption and force at break variables. These differences between the materials are a consequence of the properties of each material, for example the high oil or resin contents which, in the case of OPFM, would be the cause of these differences.

Values for the density of both types of pellet fall into the international ranges, however differences or variations of the density can be seen at the internal level, especially in the values of OPFM.

In the characterisation of the combustion process, it becomes evident that, for both types of pellets, the process was not adequate in a domestic pellet stove, so an improvement of the combustion process is due in order to make it more efficient, especially regarding residual mass and $\mathrm{O}_{2}$ emissions. Concerning the differences between the EFB and OPFM pellets, it has been established that pellets from OPFM present higher and more stable temperatures during combustion than those from EFB, which makes this type of pellet more suitable for combustion processes.

\section{ACKNOWLEDGEMENT}

The authors are grateful for the support of the Vicerrectoria de Investigación y Extension of the Instituto Tecnológico de Costa Rica, and to all the companies who contributed the materials for pellet manufacturing.

\section{REFERENCES}

AARSETH, K A and PRESTLOKKEN, E (2003). Mechanical properties of feed pellets: Weibull analysis. Biosyst. Eng., 84: 349-361.

ABUELNUOR, A A; WAHID, M A; HOSSEINI, S E; SAAT, A; SAQR, K M; SAIT, H H and OSMAN, M (2014). Characteristics of biomass in flameless combustion: a review. Renewable Sust. Energy Rev., 33: 363-370.

ARAGÓN-GARITA, S; MOYA, R; BOND, B; VALAERT, J, and TOMAZELLO FILHO, M (2016). Production and quality analysis of pellets manufactured from five potential energy crops in the Northern Region of Costa Rica. Biomass and Bioenergy, 87: 84-95.

AMERICAN SOCIETY OF MECHANICAL ENGINEERS (ASME) (2011). ASME PTC-4 Indirect Method: Stack Loss Method. 3 pp. http://www.arb. ca.gov / cc/ capand trade / allowanceallocation / boiler_efficiency_calc.pdf

ASTM (2004). D5865-04. Standard Test Method for Gross Calorific Value of Coal and Coke. ASTM International, West Conshohocken, PA. www.astm. org

ASTM (2013a). D1102-84. Standard Test Method for Ash in Wood. ASTM International, West Conshohocken, PA. www.astm.org

ASTM(2013b). D1762-84. Standard Test Method for Ash in Wood. ASTM International, West Conshohocken, PA. www.astm.org

ASTM (2013c). D1110-84. Standard Test Methods for Water Solubility of Wood. ASTM International, West Conshohocken, PA. www.astm.org 
ASTM (2013d). D1109-84. Standard Test Method for $1 \%$ Sodium Hydroxide Solubility of Wood. ASTM International, West Conshohocken, PA. www.astm. org

ASTM (2013e). D1107-96. Standard Test Method for Ethanol-toluene Solubility of Wood. ASTM International, West Conshohocken, PA. www.astm. org

ASTM (2013f). D1108-96. Standard Test Method for Dichloromethane Soluble in Wood. ASTM International, West Conshohocken, PA. www.astm.org

BERGSTROM， D; ISRAELSSON， S; OHMAN, M; DAHLQVIST, S A; GREF, R; BOMAN, C and WASTERLUND, I (2008). Effects of raw material particle size distribution on the characteristics of scots pine sawdust fuel pellets. Fuel Process. Technol., 89: 1324-1329.

BSI. DD CEN/TS 15210-1:2005 (2005). Solid biofuels. Methods for the Determination of Mechanical Durability of Pellets and Briquettes. Part 1: Pellets. Milan, Italy.

CARVALHO, L; WOPIENKA, E; POINTNER, C; LUNDGREN, J; VERMA, V K; HASLINGER, W and SCHMIDL, C (2013). Performance of a pellet boiler fired with agricultural fuels. Appl. Energy, 104: 286296.

CHEN, S F; MOWERY, R A; SCARLATA, C J and CHAMBLISS, C K (2007). Compositional analysis of water-soluble materials in corn stover. J. Agric. Food Chem, 55(15): 5912-5918.

CHIEW, Y L and SHIMADA, S (2013). Current state and environmental impact assessment for utilizing oil palm empty fruit bunches for fuel, fiber and fertilizer: a case study of Malaysia. Biomass Bioenergy, 51: 109-124.

COLLEY, Z; FASINA, O O; BRANSBY, D and LEE, Y Y (2006). Moisture effect on the physical characteristics of switchgrass pellets. Trans. ASABE, 49: 1845-1851.

DAI, J and GRACE, J R (2011). Biomass granular screw feeding: an experimental investigation. Biomass Bioenergy, 35(2): 942-55.

DEMIRBAS, A (2009). Relationships between heating value and lignin, moisture, ash and extractive contents of biomass fuels. Energy Explor. Exploit., 20: 105-111.

DEUTSCHES INSTITUT FUR NORMUNG (DIN) (1996). DIN 51731 Testing of Solid Fuels - Compressed Untreated Wood - Requirements and Testing. German National Standard. 4 pp.
FASINA, O O (2008). Physical properties of peanut, hull pellets. Bioresour. Technol., 99: 1259-1266.

GARCÍA-MARAVER, A; RAMOS-RIDAO, A F; RUIZ, D P and ZAMORANO, M (2010). Quality of pellets from olive grove residual biomass. European Association for the Development of Renewable Energies, Environment and Power Quality (EA4EPQ). Paper presented at the International Conference on Renewable Energies and Power Quality, Granad, Spain.

GILBERT, P; RYU, C; SHARIFI, V and SWITHENBANK, J (2009). Effect of process parameters on pelletisation of herbaceous crops. Fuel, 88: 1491-1497.

HERRERO, M; HAVLÍK, P; VALIN, $\mathrm{H}_{;}$ NOTENBAERT, A; RUFINO, M C; THORNTON, P K; BLUMMEL, M; WEISS, F; GRACE, D and OBERSTEINER, M (2013). Biomass use, production, feed efficiencies, and greenhouse gas emissions from global livestock systems. Proc. of the National Academy of Sciences, 110(52): 20888-20893.

HUSAIN, Z; ZAINAC, Z and ABDULLAH, Z (2002). Briquetting of palm fibre and shell from the processing of palm nuts to palm oil. Biomass Bioenergy, 22: 505-509.

INEC, INSTITUTO NACIONAL DE ESTADÍSTICA Y CENSO (INEC) (2015). http:// www.inec. go.cr / A / MS / Censos / Censo\%20Agropecuario / Publicaciones / 01.\%20 VI\%20 Censo\% 20 Nacional $\% 20$ Agropecuario, \%20Resultados $\% 20$ Gesnerales.pdf

JAIN, R K (1994). Fuelwood characteristics of medium tree and shrub species of India. Bioresour. Technol., 47: 81-4.

JOHN, M J and THOMAS, S (2008). Review biofibres and biocomposites. Carbohyd. Polym., 71: 343-364.

KATAKI, R and KONWER, D (2002). Fuelwood characteristics of indigenous tree species of Northeast India. Biomass Bioenerg., 22: 433-437.

KERDSUWAN, $\mathrm{S}$ and LAOHALIDANOND, $\mathrm{K}$ (2011). Renewable energy from palm oil empty fruit bunch. Renewable Energy - Trends and Applications (Nayeripour, M and Kheshti, M eds.). p. 123-150.

KUMAR, M; GUPTA, R C and SHARMA, T (1992. Effect of carbonization conditions on the yield and chemical composition of Acacia and Eucalyptus wood chars. Biomass Bioenergy, 3: 411-417. 
LAI, Z Y; CHUA, H B and GOH, S M (2013). Influence of process parameters on the strength of oil palm kernel shell pellets. J. Mater. Sci., 48: 14481456.

LAM, P S; LAM, P Y; SOKHANSANJ, S; LIM, J; BI, $X$ T; STEPHEN, J D; PRIDOWO, A and MABEE, W E (2015). Steam explosion of oil palm residues for the production of durable pellets. Appl. Energy, 141: 160-166.

LARSSON, S; THYREL, M; GELADI, $\mathrm{P}$ and LESTANDER, T (2008). High quality biofuel pellet production from pre-compacted low density raw materials. Bioresour. Technol., 99: 7176-7182.

LAW, K N; WAN-DAUD, W S and GHAZALI, A (2007). Morphological and chemical nature of fiber strands of oil palm empty fruit bunch. BioResources, 2(3): 351-362.

LEHTIKANGAS, P (2001). Quality properties of pelletised sawdust, logging residues and bark. Biomass Bioenergy, 20: 351-360.

LIMOUSY, L; JEGUIRIM, M; DUTOURNIÉ, P; KRAIEM, N; LAJILI, M and SAID, R (2013). Gaseous products and particulate matter emissions of biomass residential boiler fired with spent coffee grounds pellets. Fuel, 107: 323-329.

LINDSTRÖM, E; LARSSON, S H; BOSTRÖM, D and ÖHMAN, M (2010). Slagging characteristics during combustion of woody biomass pellets made from a range of different forestry assortments. Energy Fuel, 24(3): 456-461.

MANDE, S P (2009). Thermo chemical conversion of biomass. Renewable Energy Engineering and Technology Principles and Practice (V V N Kishore ed.). The Energy and Resources Institute, New Delhi. p. 705-728.

MOYA, R; MUÑOZ, F; MATA, J and SOTO, R, (2013). An anatomic comparison between bunch and fruit of oil palm with pineapple leaf and three woods from plantations in Costa Rica. J. Oil Palm Res. Vol. 25(1): 138-148.

MOYA, R and TENORIO, C (2013). Fuelwood characteristics and its relation with extractives and chemical properties of ten fast-growth species in Costa Rica. Biomass Bioenergy, 56: 14-21.

MOYA, R; RODRIGUEZ-ZUÑIGA, A; TENORIO, C; VALDEZ, J and VALAERT, J (2015a). Evaluation of the combustion of wood pellets made from tropical-climate agricultural and forestry crops of Costa Rica with a domestic stove. Waste Biomass and Valorization. DOI: 10.1007/s12649-015-942-1.
MOYA, R; CAMACHO, D; SOTO, R; MATA, J and VEGA-BAUDRIT, J (2015b). Chemical and extractives compatibility of empty bunch fruit of Elaeis guineensis, leaves of Ananas cumosos and tetra pak packages with wood used in particleboards in tropical areas. Latin America Research Applied, 45: $1-10$.

MOORE, W and JOHNSON, D (1967). Procedures for the chemical analysis of wood and wood products. Research Paper FLP Forest Service. Forest Products Laboratory, Madison, W I. 15 pp.

MUNAWAR, S S and SUBIYANTO, B (2014). Characterization of biomass pellet made from solid waste oil palm industry. Procedia Environ. Sci., 20: 336-341.

NASRIN, A B; MA, A N; CHOO, Y M; MOHAMAD, S; ROHAYA, M H; AZALI, A and ZAINAL, Z (2008). Oil palm biomass as potential substitution raw materials for commercial biomass briquettes production. Am. J. Appl. Sci., 5(3): 179-183.

OBERNBERGER, I and THEK, G (2004). Physical characterization and chemical composition of densified biomass fuels with regard to their combustion behavior. Biomass Bioenergy, 27(6): 653-669.

ÖHMAN, M; BOMAN, C; HEDMAN, H; NORDIN, A and BOSTRÖM, D (2004). Slagging tendencies of wood pellet ash during combustion in residential pellets burners. Biomass Bioenergy, 27: 585-596.

RABAÇAL, M; FERNANDES, U and COSTA, M (2013). Combustion and emission characteristics of a domestic boiler fired with pellets of pine, industrial wood wastes and peach stones. Renew Energy, 51: 220-226.

RAZUAN, R; FINNEY, K N; CHEN, Q; SHARIFI, V N and SWITHENBANK, J (2011). Pelletised fuel production from palm kernel cake. Fuel Process. Technol., 92: 609-615.

RHÉN, C; GREF, R; SJOSTROM, $\mathrm{M}$ and WASTERLUND, I (2005). Effects of raw material moisture content, densification pressure and temperature on some properties of Norway spruce pellets. Fuel Process. Technol., 87: 11- 16.

ROY, M M; DUTTA, A; CORSCADDEN, K and HAVARD, P (2011). Co-combustion of biosolids with wood pellets in a wood pellet stove. Int J Eng Technol., 11(3): 7-15.

SEIFERT, K (1960). Zur frage der celluloseschnellbestimmung nach der acetylaceton-methode. Das Papier, 14: 104-106. 
SERRANO, C; MONEDERO, E; LAPUERTA, $\mathrm{M}$ and PORTERO, H (2011). Effect of moisture content, particle size and pine addition on quality parameters of barley straw pellets. Fuel Process. Technol., 92: 699706.

SHUIT, SH; TAN, K T; LEE, KT and KAMARUDDIN, A H (2009). Oil palm biomass as a sustainable energy source: a Malaysian case study. Energy, 34: 1225-1235.

SIS (1998). SS 1871 20. Biofuels and Peat - Fuel Pellets Classification. Swedish Standards Institution, STG Classification, Stockholm.

STELTE, W; HOLM, J K; SANADI, A R; BARSBERG, S; ANNENFELDT, J and HENRIKSEN, U B (2011). A study of bonding and failure mechanism in fuel pellets from different biomass resources. Biomass Bioenergy, 35: 910-918.

SUKIRAN, M A; CHIN, C M and ABU BAKAR, N $\mathrm{K}$ (2009). Bio-oils from pyrolysis of oil palm empty fruit bunches. Am. J. Appl. Sci., 6(5): 869-875

TAMAKI, Y and MAZZA, G (2010). Measurement of structural carbohydrates, lignins, and microcomponents of straw and shives: effects of extractives, particle size and crop species. Ind. Crops and Prod., 31(3): 534-541.

TABIL, L and SOKHANSANJ, S (1996). Process conditions affecting the physical quality of alfalfa pellets. Appl. Eng. Agric.: 345-350.

TECHNICAL ASSOCIATION OF THE PULP and PAPER INDUSTRY (TAPPI) (2002). Tappi T 222 om-02 revised 2002. Standard Test for Acid-insoluble Lignin in Wood and Pulp. Parkway South Norcross, US, TAPPI.

TENORIO, C and MOYA, R (2012). Evaluation of different approaches for the drying of lignocellulose residues. BioResources, 7(3): 3500-3514.

TENORIO, C; MOYA, R; TOMAZELLO FILHO, M and VALAERT, J (2015a). Application of the X-ray densitometry in the evaluation of the quality and mechanical properties of biomass pellets. Fuel Process. Technol., 132: 62-73.

TENORIO, C; MOYA, R; TOMAZELLO FILHO, M and VALAERT, J (2015b). Quality of pellets made from agricultural and forestry crops in Costa Rican tropical climates. BioResources, 10(1): 482-498.

THAMMASOUK, K; TANDJO, D and PENNER, M $H$ (1997). Influence of extractives on the analysis of herbaceous biomass. J. Agric. Food Chem, 45(2): $437-$ 443.

THEERARATTANANOONA, K; XUA, F; WILSONB, J; BALLARDC, R; MCKINNEYB, L; STAGGENBORGC, S; VADLANIB, P; PEID, Z J and WANG, D (2011). Physical properties of pellets made from sorghum stalk, corn stover, wheat straw, and big bluestem. Ind. Crops Prod., 33: 325-332.

TORRES, R; ACOSTA, Á and CHINCHILLA, C (2004). Proyecto comercial de compostaje de los desechos agroindustriales de la palma aceitera. Revista Palmas, 25: 377-387.

TRIANOSKI, R; IWAKIRI, S and DE MATOS, J L M (2011). Potential use of planted fast-growing species for particleboard. J. Trop. For. Sci., 23(3): 311-317.

VERMA, V K; BRAM, S; DELATTIN, F; LAHA, P; VANDENDAEL, I; HUBIN, A and DE RUYCK, J (2012). Agro-pellets for domestic heating boilers: standard laboratory and real life performance. Appl. Energy, 90: 17-23.

WAHI, R; HGAINI, Z and USUN JOK, V (2009). Removal of mercury, lead and copper from aqueous solution by activated carbon of palm oil empty fruit bunch. World Appl. Sci. J., 5 (Special Issue for Environment): 84-91.

WALKER, N K and DOBB, R S (1988). Calculation of wood density variation from $\mathrm{X}$-ray densitometer data. Wood Fiber Sci., 20: 35-43.

WHITE, R H (1987). Effect of lignin content and extractives on the higher heating value of wood. Wood Fiber Sci., 19: 446-452. 